\title{
eLyra
}

REVISTA DA REDE INTERNACIONAL LYRACOMPOETICS

\section{O lirismo impossível: poesia e litanias ${ }^{1}$}

\author{
Autoria: Gabrielle Althen (Colette Astier) \\ Tradução: Francine F. Weiss Ricieri (UNIFESP- SP) \\ Maria Lúcia Dias Mendes (UNIFESP-SP)
}

Resumo: O ensaio discute o caráter artificioso da poesia. Haveria similaridade com o que ocorre não com textos ordinariamente chamados místicos, mas com poemas místicos, quando são verdadeiramente poemas (de que seriam bom exemplo poemas de São João da Cruz). Nesse sentido, a litania forneceria um bom contraponto, por se constituir em gênero que parece apostar na convergência entre o sujeito que ora e o destinatário de sua oração. Astier propõe a reaproximação entre litanias religiosas e um poema de T. S. Eliot, que se confere andamento de litania e se propõe como poema efetivo e falsamente litânico. A comparação entre uma forma prescrita pela tradição e a estrofe do "Ash Wednesday" (que a evoca) é combinada com o exame de dois poemas intitulados "Dévotion", um de Rimbaud, outro de Bonnefoy, sendo que o segundo se apresenta como prolongamento do primeiro. São dois poemas de invocação nos quais o sujeito lírico se projeta até o ponto de quase desaparecer da cena verbal. Ambos se reaproximam da postura implicada pela recitação de litanias, em especial pela atitude exclamativa, estudada por Valéry, Octavio Paz e Maulpoix. Astier enfatiza a necessidade de focar não a fugacidade da exclamação, mas a atitude psíquica que revela. Como na mística, em que a contemplação procederia de um esvaziamento do sujeito, também as fórmulas verbais exclamativas revelariam a síncope de um sujeito, seu silêncio, sua inação. O sujeito lírico, aspirado pelo mundo e pelo objeto de seu desejo é transportado. O êxtase, no sentido original, procederia deste transporte. Nas litanias, com efeito, o processo é simples e repetitivo, reorganizando a contemplação de verso em verso, sem progressão. Esta forma é tomada de empréstimo por Eliot, mas o poema desenvolve, de uma perspectiva religiosa explícita, uma meditação sobre o poder da palavra poética. O ensaio também aborda pelo menos dois recursos paralelos aos 
procedimentos exclamativos. O primeiro se relaciona com um retorno à narração e o segundo à própria música e suas suspensões.

Résumé: L'essai discute le caractère artificieux de la poésie. Il n'y aurait pas de similitude avec ce qui se passe dans des textes ordinairement appelés mystiques, mais il y aurait avec les poèmes mystiques, quand ils sont vraiment des poèmes (les poèmes de Saint Jean de la Croix étant de bons exemples de cela). Dans ce sens, la litanie fournirait un bon contrepoint, parce qu'elle se constitue dans un genre qui semble parier à la convergence entre le sujet qui prie et le sujet de sa prière. Astier propose le rapprochement entre les litanies religieuses et un poème de T. S. Eliot, dans lequel il donne un mouvement verbal de litanie et il est proposé comme poème effectif et comme faussement liturgique. La comparaison entre une forme pré-écrite par la traduction et la strophe d'«Ash Wednesday» (qui l'évoque) est combinée avec l'examen des deux poèmes intitulés «Dévotion», l'un de Rimbaud, l'autre de Bonnefoy, étant donné que le second se présente comme la prolongation du premier. II s'agit de deux poèmes d'invocation, dans lesquels le sujet lyrique se projette jusqu'au point de presque disparaître de la scène verbale. Les deux se rapprochent de la posture impliquée par la récitation de litanies, en spécial par l'attitude exclamative, étudiée par Valéry, Octavio Paz et Maulpoix. Astier donne l'emphase à la nécessité de ne pas mettre l'accent sur la fugacité de l'exclamation, mais sur l'attitude psychique qu'elle révèle. Comme dans la mystique, dans laquelle la contemplation procéderait d'un vidage du sujet, les formules verbales exclamatives révéleraient-elles aussi la syncope d'un sujet, son silence, son inaction. Le sujet lyrique, aspiré par le monde et par l'objet de son désir, est transporté. L'extase, dans le sens original, procéderait de ce transport. Dans les litanies, en effet, le processus est simple et répétitif, réorganisant la contemplation de vers en vers, sans progression. Cette forme est empruntée par Eliot, mais le poème développe, d'une perspective religieuse explicite, une médiation sur le pouvoir de la parole poétique. L'essai aborde, au moins, deux ressources parallèles aux processus exclamatifs. Le premier est relatif à un retour à la narration et le second à la musique même et ses suspensions.

O lirismo impossível, poesia e litanias: talvez a reunião dessas palavras mostre-se um pouco insólita. Talvez seja ainda um pouco provocante. Eu me permiti, no entanto, propor esse título para as reflexões que se seguem com o propósito de ilustrar uma questão relativa à poesia, se não à literatura em seu conjunto, questão que revela ser ela própria profundamente provocante. Ocorre de fato que essa questão suscita dúvida, uma dúvida que não cessa de assombrar os poetas contemporâneos: Na llusão do Limiar, $^{2}$ propunha 
recentemente Yves Bonnefoy como título de uma coletânea, aludindo a uma desconfiança que ele compartilhava com Michel Deguy. A veracidade do poema tornou-se, com efeito, nesse sentido, objeto de poema a ponto de mesmo um poeta como René Char (com uma obra suscetível de requalificar o homem) poder vir a avaliá-la em termos de suspeição em alguns de seus poemas importantes. Que nos lembremos, por uma vez, não da primeira estrofe tão frequentemente citada por sua feliz graça, do poema das Matinaux intitulado "Cet amor à tous retiré", ${ }^{3}$ mas de sua última:

L'avantage au vaillant mensonge

Est la franche consolation (Char 1983: 305) ${ }^{4}$

Será que a graça aí vem a se deixar levar pela dúvida? Pior, deveria ela ser tomada por mentira? E, pior ainda, essa mentira deveria ser tomada como signo de bravura, como signo de liberdade, e até, se nos referimos ao título por si só bastante inquietante do poema, como aquele da única liberdade que temos? Mas que pensemos também no argumento tão estranho e finalmente tão doloroso de Newton cassa la mise en scène, ${ }^{5}$ segundo o qual seria suficiente chamar de maçã a um crânio para que esse objeto embaraçoso apareça sous le traits ruisselants et tout aussi ambigus du poème (Girard 1951: 544 ). ${ }^{6}$ O poema preserva então ao mesmo tempo a advertência das Vaidades de outros tempos, ainda que suas representações possam se encontrar suprimidas pelas teorias de Newton, e o desconforto de se querer apaixonado, com um objeto tão incômodo quanto o gosto da morte em sua boca. Mas se a relação entre a palavra e a coisa é assim tão arriscada, ou a relação entre a coisa e a palavra, se nenhum poeta cuidadoso de sua própria deontologia pode deixar de a evocar, esse risco abriga entretanto um outro, que se liga à relação de todo modo controvertida do sujeito lírico com o objeto que ele deseja. Ainda essa vez, como se descanso algum fosse de qualquer modo possível, reaparece o mesmo perigo, o mesmo perigo de mentir ou de se iludir, a ponto de vir ao espírito a ideia de se perguntar se a literatura, em seu princípio, não é suficientemente artificiosa para ocultar o objeto que ela finge procurar. Ela seria apenas a transcrição de um processo ou da busca na qual ela assumiria sempre a tarefa de desviar os eventuais desfechos felizes, sob pena de não ser mais literatura. Iriam nesse sentido não apenas os textos que se costuma habitualmente tomar por místicos, já que eles fazem o que 
podem com os recursos da língua, mas os poemas místicos, quando eles são verdadeiramente poemas, dentre os quais os de São João da Cruz fornecem um exemplo privilegiado. Ora esse último se mostra singularmente atento, precisamente porque ele é poeta, em desposar os diferentes ritmos de duas demandas (da esposa e do Esposo), a ponto de sua união terminar por ser lá figurada como o desejo de união. Ainda essa vez, o descanso parece alheio ao que é especificamente literário. Em um domínio totalmente diferente, há uma palavra sintomática de René Girard que é, sob esse aspecto, muito interessante mesmo que ela apareça nas sinuosidades de uma frase do final de Mentira Romântica e Verdade Romanesca (Girard 1951). Essa palavra inesperada e singular no contexto de grandes obras romanescas às quais ela se aplica não é nada menos que desajeitado. ${ }^{7}$ Desajeitado será o tom da conclusão dos grandes romances que constituem o corpus sobre o qual se apoiou todo esse livro. Desajeitados portanto os capítulos que, segundo as análises do autor, conduziriam seus heróis em segurança? Mas de qual falta de jeito se trata aqui? E, sobretudo, essa falta de jeito não será, mais que aquela dos grandes romancistas dos quais ele tratou, aquela do próprio processo literário? Talvez seja necessário disso deduzir um tipo de índice daquilo que a literatura constitui bem, esse espelho para as $\operatorname{cotovias}^{8}$ que nos conduz na direção que ela quer e não na direção que nós queremos. De fato, sua essência poderia bem ser de sempre prometer mais do que poderá manter. Podemos então nos perguntar qual é a posição do sujeito lírico no centro de uma problemática que o ultrapassa e é conveniente, nesse sentido, considerar seus trajetos possíveis ou impossíveis em relação ao objeto de seu desejo.

Mas e a litania, então? Ela constitui provavelmente um gênero interessante, em parte a título de contra-exemplo, em parte porque ela constitui um exemplo limite para esse propósito, na medida em que parece apostar, ao contrário do que evoquei, na convergência do sujeito que ora e do destinatário de sua oração. Portanto, também aposta, se ela chega a se constituir como poema, na aliança entre esse sujeito lírico e seu objeto. Contrariamente às dúvidas que acabaram de ser consideradas, a litania privilegia nesse sentido uma das posturas singulares exemplares do sujeito lírico com respeito a seu desejo, a saber, aquela em que ele se coloca à altura desse último. Mas isto é também o característico da contemplação. Sujeito desejante e objeto de desejo aí se enfrentam e o sujeito lírico ou contemplativo deveria poder permanecer ligado indissoluvelmente ao mais elevado de sua meditação. Ora, essa 
singularidade, em si mesma significativa, parece-me ainda mais interessante para esse propósito, se um poeta importante tentou recuperar sua forma e provavelmente o motivo, de litanias a Maria, em seu benefício, sem renunciar a seus procedimentos poéticos próprios. 0 que equivale a dizer que ele perverteu aquilo que tomou emprestado. Perversão preciosa no que concerne a estas análises. Perversão ainda mais preciosa mesmo que não seja exercida com fins ideológicos, levados em conta os engajamentos religiosos expressamente enunciados pelo poeta, mas com fins estritamente poéticos. Dessa maneira se encontram assentadas as balizas dessa reflexão. São balizas de uma reflexão mais geral sobre os caminhos tão específicos da literatura e do poema, a reaproximação entre litanias religiosas e o poema de T. S. Eliot que assume andamento de litanias e se propõe de todo modo como um poema efetivo e falsamente litânico. Quanto à reflexão, muito parcial, que se propõe aqui, ela tentará revelar e tornar claras certas trajetórias poéticas ou a-poéticas do sujeito lírico, como sujeito de seu desejo. O exame do texto de Eliot e do gênero ao qual ele se filia talvez tenha permitido ancorar esse esforço de compreensão na letra do poema. O cuidado de que procede essa análise é, portanto, de colocar em processo o sujeito lírico. Enfim, para melhor encarnar esse propósito, a comparação de uma forma prescrita pela tradição e a estrofe do "Quarta-feira de cinzas" (Eliot 1981: 121-130) ${ }^{9}$ com a qual se assemelha, será combinada com o exame de dois outros textos destinados cada um a teorizar a análise em questão. A particularidade desses dois textos é que podemos considerar que eles se organizam em dípticos, o que se liga de todo modo ao fato de que são poemas, dois poemas igualmente intitulados "Devoção", um de Rimbaud e outro de Bonnefoy, sendo que o segundo se oferece como uma forma de prolongamento do primeiro. Os dois fornecem, de fato, na letra e pela letra do lirismo, o fundamento de toda uma meditação teorizante sobre o possível do poema. O primeiro, de forma abrupta e quase brutal, propõe um núcleo de percepções e de análises da atitude do sujeito invocante cuja metáfora o segundo ampliará. Ocorre também que esses dois poemas, que são poemas de invocação e que se aproximam sob esse aspecto da postura implicada na recitação das litanias, têm por particularidade isolar certas atitudes específicas do sujeito lírico e colocar a descoberto, como in vitro, um certo número de sintomas que me parecem característicos das apostas do lirismo e da poesia em geral. 
Nietzsche (1949), em O Nascimento da Tragédia, definia o poeta lírico como aquele que compreende a natureza inteira e se compreende a si mesmo nela, como a força eterna que quer, deseja, aspira. Na mesma página, ele enunciava antes que a vontade do poeta, seus desejos, seus suspiros, seus gritos de alegria, servem-Ihe de metáforas. Sem dúvida a ideia que é preciso reter é que todo desejo pode servir de metáfora a outras questões. Passo portanto para a argumentação segundo a qual a oposição de um desejo ou de um eu ditos subjetivos ou objetivos é controlada, para não levar em conta o fato que o moi e o je do poeta ultrapassam a individualidade, - ou melhor dela se servem - para aí encontrar a metáfora e o argumento de um desejo universal. Nessa perspectiva, o projeto do sujeito lírico, seu cuidado ou seu trabalho, tal como está inscrito no poema, é de espera do objeto do desejo. No fundo, a única tentação que há é a reunião de sujeito e objeto, seu agrupamento ou mesmo, se fosse o caso de antecipar os resultados prometidos pelo texto, sua fusão, sua confusão e sua efusão comuns. Essa é a postura desejada, senão desejável do sujeito lírico que me interessa aqui e a partir da qual considero possível chegar a alguns esclarecimentos sobre a maquinaria poética em geral.

É portanto uma postura festiva, sem dúvida uma postura limite, essa eventual junção do sujeito e do objeto de seu desejo, se for verdade que o absoluto desse encontro não se reduz a nada de muito comum. Aliás, a surpresa desse encontro, mesmo que organizada pelo poema, nele cria um efeito de escansão que tem por baliza sintática e rítmica privilegiada a exclamação. Mas, observando melhor, a atitude exclamativa, como a palavra ou a síncope da palavra próprias ao sujeito lírico, ao mesmo tempo que são signos, fazem signos.

Sem dúvida, não é muito novo evocar essa ligação do lirismo e da exclamação. Valéry a tinha estabelecido expressamente na Tel Quel, mas, mais próximo de nós, Octavio Paz e, depois dele, Jean-Michel Maulpoix descrevem a poesia lírica segundo os procedimentos de uma alternância dialética do desenvolvimento que é, no poema, ao mesmo tempo aquilo que conduz à exclamação e aquilo que dela deriva. ${ }^{10}$ No entanto, para além desse mecanismo, a propósito do qual está atestado, com efeito, sua recorrência, será necessário talvez estabelecer ligação, não somente com a fugacidade evidente da exclamação, mas com a atitude psíquica que ela revela. Em Poèmes de la presqu'île, Michel Deguy (Deguy 1961: 139) citado por Jean-Michel Maulpoix, já interrogava o charme, segundo suas próprias palavras, da 
frase exclamativa, especialmente de duas formas caracterizadas por sua abertura em oh... ou em $\hat{o}$, cujo uso é tão marcado na poesia a ponto de às vezes ser tomado por sinal exterior do poema. Talvez não seja completamente inútil tentar escrutinar as idas e vindas que se instituem entre alguns desses arranjos sintáticos e o que eles indicam a propósito daquele que os pronuncia. Ora, aqueles que proferem o verbo deixam escapar, no conjunto, alguns índices preciosos e dentre eles estão particularmente as fórmulas que derivam da invocação, qualquer que seja, suspeitamos, a instância invocada. Um exemplo tomado de Baudelaire permitirá a análise:

\footnotetext{
Ó tosão que até a nuca encrespa-se em cachoeira!

Ó cachos! Ó perfume que o ócio faz intenso!

Êxtase! (Baudelaire 1985: 159) ${ }^{11}$
}

O que esses versos assinalam de modo claro, de saída, é a inversão ou o esvaziamento radical do sujeito da invocação por aquilo que ele invocou. Mas, não nos enganemos a respeito, exemplo assim tão límpido terá sido difícil de encontrar e, contrariamente àquilo em que poderíamos acreditar, há poucos poemas em As Flores do Mal que designam assim tão precisamente tal encontro. Por isso é necessário perguntar antes sobre sua natureza. Certamente, na surpresa do face a face assim instaurado, o que se diz mantém, ao menos na mesma medida do encontro, um desequilíbrio insistente entre duas polaridades do desejo. Pode-se dizer do par composto pelo sujeito e seu objeto: um se cala para deixar plenamente ao outro o seu lugar. Deixar plenamente o lugar, por assim dizer, para esse que precisamente nos ocupa em toda a extensão do campo verbal. De onde a relativa raridade do procedimento. Como se sabe, a experiência não poderia ser indefinidamente repetida e os poemas que se arriscam a recorrer a ela são menos frequentes do que a memória desejaria registrar, o que não faz essa falha de memória deixar de ser significativa, já que tende a revelar uma predileção pelas figuras de estilo em que o sujeito se entrega a seu objeto. Do mesmo modo, a mística não diz outra coisa. A contemplação procede em todo caso de um esvaziamento de um pelo outro e do interno pelo externo. Disso são testemunha também as fórmulas exclamativas não verbais: de uma síncope do sujeito. De seu silêncio. No sentido próprio, de sua inação. 0 
sujeito lírico, inspirado ou aspirado pelo mundo e pelo objeto de seu desejo é transportado. O êxtase, no sentido original procede com efeito desse transporte, ou dessa transferência.

Esses, de fato, podem ser dotados de vários modos que, como na física, podem ser qualificados de centrífugos ou centrípetos. Nessa perspectiva, pode-se denominar centrífugo o transporte que vai do sujeito em direção ao objeto e "Devoção", de Rimbaud, é construído por essa modalidade. Ao inverso, temos o caso das litanias contemplativas em que o objeto de fervor vem, de modo centrípeto, investir o sujeito invocante e-quem sabe? - não somente o fazer calar por um momento, mas se substituir a ele. No final, pouco importa o sentido desses movimentos. É constante, por outro lado, o que se relaciona com uma forma de descentramento do sujeito. Descentramento, excentramento, êxtase, há muitos resultados para esse transporte dos quais a psicanálise pode extrair todas as lições que desejar quanto à frieza do sujeito diante da ameaça de seu próprio desejo. Esse eu ausente pelo simples fato de que ele é prisioneiro de seu objeto, esse eu retirado de si mesmo no momento de se confrontar com esse objeto, não deve evidentemente ser confundido com aquele que se exprime ao se calar, como demonstrou Michel Collot a propósito de Reverdy (Collot 1994: 3542). O eu em questão é somente um eu construído, que deve provavelmente ser interpretado como uma figuração da relação, seja com a falta, seja com o excesso, e, em todo caso, com esse abismo do outro ao qual Nietzsche fazia referência: “O 'eu' do poeta lírico soa portanto a partir do abismo do ser" (Nietzsche 2005: 45).

Reunir a outra polaridade de seu desejo, como aliás não a reunir, é descobrir isso que Nietzsche chama ainda de a dor e a contradição originais de que a paixão individual é a metáfora. O transporte lírico, alcançado em seu acme exclamativo carrega assim a dor dessa negociação entre perda, vazio abissal e mortal do ser e possessão do objeto combinado com um eclipse do eu.

Aí, provavelmente, reside a vocação do lirismo. Ao menos sua vocação confessada e aquela cuja necessidade é comumente partilhada. Nem a literatura nem a poesia são portanto tão claras e não tenho certeza de que, por mais importante que seja o princípio dessa vocação, ela não procede de um voto piedoso. De um voto piedoso, ou de um voto insuportável e, talvez ainda uma vez, do signo da ilusão de que essas reflexões partem. Paradoxalmente, no entanto, nem a mentira nem a ilusão conseguem elevar algo à eficácia do lirismo. Ao contrário 
até e esse é o momento de uma nova constatação segundo a qual o impossível da língua poderia bem ser apenas o decalque do impossível da psique, do fato único de que o êxtase, como a exclamação fugaz que ele suscita, não são absolutamente duráveis. Mais ainda, eles não são duráveis porque não são sustentáveis. Muito cedo, a palavra e o poema, como o próprio sujeito, têm necessidade novamente de exercício, de um exercício do sujeito, a saber de seu pleno exercício de sujeito verbal, ou seja, no que concerne ao sujeito, de um novo exercício de si. De fato, de sua intervenção ativa e da narração que ela induz. Em suma, não somente daquilo que Paz e Jean Michel Maulpoix podiam denominar o desenvolvimento, senão de ação, de germes de ação, o que é de uma natureza totalmente diferente. De onde a relativa raridade de poemas desse tipo. O êxtase exclamativo corresponde a um cimo sobre o qual é difícil se instalar.

Ora, é aqui que uma rápida comparação entre o modo de funcionamento das litanias religiosas e da estrofe de T. S. Eliot permite ao mesmo tempo precisar esse questionamento e fazê-lo reverberar. Nas litanias, com efeito, o processo é ao mesmo tempo simples e repetitivo, o que não subtrai nada de sua eficácia, ainda que seja necessário se perguntar se se trata de uma eficácia de fervor ou de poema. Nenhum outro mecanismo, com efeito, além desse ligado à encantação, senão expulsar de verso em verso, ou de versículo em versículo, a pessoa do sujeito, que não tem literalmente nada de mais próprio a exprimir, em benefício da presença ou da onipresença do objeto de sua contemplação. O sujeito assim investido não tem portanto nada mais a dizer de si nem a se dizer. Também não tem mais nada a fazer e não tem outro espaço de palavra que aquele da declinação das qualidades teológicas, mesmo que sejam metaforicamente expressas, do Outro. De onde deriva a sucessão extasiada de metáforas admirativas. De onde a declinação de suas designações felizes. Desse fato, o processo das litanias, fundamentalmente reiterativo, deve retomar a contemplação de verso em verso. É a forma verbal mais preocupada com o efeito de fazer durar a emoção. Daí advém que o gênero que ela constitui, contrariamente a tantos gêneros literários, não se funda sobre a necessidade de uma progressão e não tem evidentemente razão para a fazer. De onde, ainda, o fato de que a recuperação, senão do mesmo, ao menos de quase o mesmo, nesse caso é suficiente. 
Essa é portanto a forma tomada de empréstimo por Eliot em uma estrofe de "Quartafeira de cinzas", cuja temática é ainda mais significativa para esse propósito a ponto de o poema desdobrar, do interior de uma visão religiosa explícita, toda uma meditação sobre o poder ou sobre a importância da palavra poética. O poema "Quarta-feira de cinzas", segundo a definição que Starobinski criou para a poesia de Char, revela-se com efeito um poema do poema. (Starobinski 1968). O texto escolhe como objeto o escrutínio, sem complacência, mas estamos também sob a herança de Joyce - os meios de uma palavra e de um verbo destituídos de maiúsculas e que possuem apenas esse mundo para partilhar. Esse significado entretanto não é tão excêntrico quanto parece para esse propósito já que, por mais iminente que ela seja para Eliot, a temática religiosa torna-se um meio de testar a extensão do poder poético.

Não é momento, ainda que isso dê a dimensão de um texto extremamente denso, de nos demorarmos sobre a mitologia violenta convocada no início da estrofe, para equilibrar e tornar expressiva uma tradicional figura de Virgem que pode incorrer em um risco de afetação. Ora, sua silhueta suplicante encontra sua graça na contradição que lhe acrescentam dois leopardos encarregados de devorar o pecado e os seres que se assemelham a nós, até que a intervenção do pronome pessoal que nos designa explicitamente torna comovente a carga emocional da visão. Também não é o lugar de evocar os surpreendentes avisos de Ezequiel, a quem o poema deve suas reversões mais surpreendentes e que conduzem sem dúvida à questão da invenção poética, nem mesmo de questionar a figura de mediadora que assombra todo o poema. O arremedo de litania, que não ocupa mesmo uma estrofe inteira, é em si mesmo, por esse fato singular, rico de ensinamentos. É suficiente, em todo caso, para permitir opor sujeito do poema e sujeito devocional, sujeito em contradição e sujeito em oração.

Para o que constitui a forma tradicional, a litania é muito simplesmente retomada. A referência é designada, de modo fundamentado. 0 tom permanece o mesmo que aquele das litanias e a passagem se compõe, com efeito, de uma adição de extratos de elogios todos eles endereçados à Dama:

Senhora dos silêncios

Serena e aflita 
Lacerada e indivisa

Rosa da memória

Rosa do oblívio

Exânime e instigante

Atormentada tranquila

A única Rosa [...] (Eliot 1981: 123) ${ }^{12}$

São reconhecíveis portanto as imagens tradicionais da rosa ou do jardim. A personagem do piedoso da estrofe se torna, por outro lado, a Virgem, depois a Mãe. Muitos empréstimos. Muitas reminiscências que poderiam contar muito. Ou que se tornam apenas pano de fundo. Eliot é um poeta bom demais para se contentar com isso. Em outras palavras, ele se serve de uma forma e do contexto religioso que ela implica, para curvar ambos à lei de seu poema, àquela do poema em geral e, talvez, à da própria literatura. Desde a estrofe anunciada, com efeito, desde sua segunda proposição, as imagens que deveriam ser teológicas ou extáticas revelam sua cisão. Em outras palavras, o verso está em germe se admitirmos no entanto que não se trata aqui absolutamente de valor ético mas de estética e mais particularmente de um jogo com uma matéria verbal suscetível de se moldar à experiência existencial. Daí deriva também que a Dama do poema é ainda mais próxima dos seres que nós somos, por não ser apenas ao mesmo tempo tranquila e angustiada, mas também, um pouco mais tarde, dilacerada e dilacerante, extenuada e vivificante, atormentada e repousante. Enquanto o exercício de contemplação desejaria fazer durar a lição do melhor, o poema termina sempre por distinguir isso que ele é disso que ele designa, em nome, de resto, de um estranho realismo, estruturalmente poético, que, para se parecer conosco, obriga a própria figura da unidade, mesmo que seja objeto de fé, a se deixar atravessar pela contradição. Em suma, pela divisão, como se a literatura, em seu princípio, devesse ser menos extática, mais conflituosa, e - quem sabe? - mais artificiosa que as litanias sobre as quais ela se apoia.

Eliot se serviu portanto de uma forma para dela tirar a mensagem do lado ordinário do coração dos homens, que continua, como pode, a se emocionar. Melhor, o poeta em si, porque era poeta e por nenhuma outra razão que possa ser exterior à lei poética, terá entregue a forma do louvor em si mesma a uma insegurança, a uma instabilidade primitiva e original. Em outros lugares, de resto, ele é bem sucedido com a mesma virtuosidade em 
aclimatar, como palavra de outra origem, restos de oração a versos admiravelmente pesados de incertezas e dos desembaraços do mundo e da interioridade. ${ }^{13}$ Em outras palavras, 0 poema, para ser poema, terá desistido da formulação banal do preferível e da efusão em si mesma, para adquirir ou para readquirir o acidente de seus próprios contrastes que constitui sua própria lei. De fato essa, que é a lei do poema, terá sobrepujado a lei religiosa, no interior de um discurso que permanece autenticamente religioso. O que tento designar aqui corresponde, no final, a uma forma de deslocamento das inflexões, não da mensagem. Enquanto o Verbo bíblico ao qual Eliot aspira é signo de uma união entre humanidade e divindade, ele diz a divisão da obra na língua, no coração e na experiência dos homens. De fato, por mais profundamente engajado que seja, ele não atinge o ponto em que a figura da dúvida, da oposição ou da contradição não cheguem a se manifestar em seu texto, a fim de nele restabelecer e ressaltar as polaridades do desejo. Ele enuncia, enfim, esse princípio em proposições cruéis e luminosas ao meio e ao fim da estrofe:

Extinto o tormento

Do amor insatisfeito

Da aflição maior ainda

Do amor já satisfeito (Eliot 1985: 125) ${ }^{14}$

ou ainda:

\author{
Louvemos a Mãe \\ Pelo Jardim \\ Onde todo amor termina (ibidem $)^{15}$
}

No entanto, para permanecer na ordem estrita do que estamos tratando aqui, ainda se impõe uma observação que implica uma nova perversão da forma inicial, sem que, ainda essa vez, a palavra comporte julgamento de valor: é, com efeito, o fato, nada menos o simples fato, de que o verbo, implícito em inglês, explicita-se em sua tradução, retorna à estrofe. Melhor ainda, trata-se de um verbo cujo sujeito recruta o próprio locutor e a nós com ele. É portanto um verbo que convoca novamente o sujeito lírico, mesmo se ele deixa de se apresentar como tal nesse mesmo momento e nos convoca com ele. Rendamos graças, diz 
então o poema, que reintegra, para além de seu esforço de contemplação efusiva e, sem dúvida, contra a oração e contra a litania, uma nova ocasião de liberdade ativa do sujeito. Isso não é tudo. Além do verbo efetivamente pronunciado, pode-se ainda ouvir, na estrofe, a presença de um verbo latente, não explícito e no entanto o único suscetível de estabelecer uma intersecção entre os pares de contrastes já evocados. Isso implica provavelmente um desvio que não é outro senão o das oposições, serena e aflita, lacerada e indivisa, exânime e instigante, atormentada e tranquila, memória e oblívio (ibidem $)^{16}$ que, além do dilaceramento existencial, íntimo, que elas significam, evocam também, mesmo que seja de modo tácito, a narração. Elas obrigam, em todo caso, de modo intrínseco à passagem, ao movimento e à dialética.

O poema se constrói assim em seu próprio turbilhão, em que, talvez, possamos nos reconhecer. Sem dúvida que, não podendo permanecer por muito tempo sob o êxtase da litania, não podendo se desenvolver sobre a elisão do sujeito lírico, ele reencontra bem rápido suas garras, seus humores, suas lágrimas e seus arrebatamentos, que, provavelmente, também a nós se referem. Isso não significa dizer que não exista literatura que seja ao mesmo tempo literária e mística. O exemplo, raro, de São João da Cruz ou dos poetas Soufi, é suficiente para afastar essa ideia. Por outro lado, a suspensão do sujeito, quer ele seja lírico ou místico não pode fundar o poema como tal. No que concerne a São João da Cruz, mesmo se não for aqui o lugar de desenvolver os motivos que levam a isso, é característico que a poesia se valorize no poema pela reinserção de uma dramaturgia. Dramaturgia de dois desejos que se afrontam, dramaturgia de dois desejos que se buscam, a ponto de muitas de suas estrofes substituírem sub-repticiamente, como já o fazia o Cântico dos Cânticos, o êxtase pela busca do êxtase. O próprio cervo do Cântico Espiritual busca a esposa a ponto de seu reencontro se deslocar para o final do canto. A obra era de um místico e de um poeta, ou de um místico que era também poeta. Quanto a Eliot, não somente porque ele era poeta, mas talvez também porque ele não era senão poeta, não se poderia pretender mais que a indecisão, - exatamente no núcleo do que ele tinha por assegurado.

Essa análise poderia enfim ser prolongada pela convocação, a título de contraexemplo, destinado, entretanto, a se transformar muito rápido em exemplo, de um breve poema de Rimbaud, subsidiário nesse percurso. Com efeito, de modo diferente do que ocorre 
em Eliot, o amigo, em "Vigílias", não é nem ardente, nem fraco, ao mesmo tempo que a amada nem atormentante nem atormentada, como o repouso, nem febre, nem langor. As entidades desejáveis assim enunciadas se distribuem, portanto, virgens de contradições e, efetivamente, a visão se propõe, ao contrário do que ocorre em "Quarta-feira de cinzas", sem cisões. Não seria necessário acreditar por tudo isso que Rimbaud carece, na expressão de seu sonho idílico, de um funcionamento do poema que chego a considerar fundador. Se observarmos mais de perto, não somente a contradição não está ausente desse texto, como também a ele retorna com força, no momento preciso em que se deseja consentir a visão: em suas últimas palavras. Tudo ocorre nesse curto poema como ocorre tão frequentemente nas Iluminações: Rimbaud anula suas proposições felizes. É que elas, de fato, por vezes, de modo surpreendente aplainadas, não fazem poemas senão através de suas retomadas. A exclusão da contradição não havia portanto fornecido senão uma falsa aparência de curta duração. Um desmentido vem de uma só vez expulsá-la: "E o sonho arrefece" (Rimbaud 1998: 253). Essas são as últimas palavras do poema: um dobre de finados.

O idílio que não tinha sido denunciado, no mesmo momento em que ele tinha sido anunciado, em uma forma de telescopagem da esperança e do desespero, como acontece com tanta frequência nas /luminações, é assim rasurado e abandonado (Rimbaud 1998: 253). ${ }^{17}$

São portanto dois métodos opostos cujo princípio permanece o mesmo. Princípio doloroso que tem talvez relação com a constatação de que o melhor, contrariamente a isso que se deseja, não reside aqui ou não é para hoje. Em todo caso, é de um virulento princípio de dissociação de que se trata aqui e sua teoria é claramente identificável nos dois poemas de Rimbaud e de Bonnefoy intitulados "Devoção". ${ }^{18}$ Esses dois poemas têm, com efeito, por particularidade, se é verdade que certas obras são suscetíveis de estabelecer a lei de seu próprio processo, de serem poemas enunciando a lei que os constituiu.

São portanto dois poemas de invocação, nos quais o sujeito lírico se projeta, como foi dito, até desaparecer da cena verbal. Pouco importa para esse propósito, o objeto das devoções que emprestam seus títulos aos dois textos. Pouco importam, em particular, as diferentes chaves que já se propuseram para o poema de Rimbaud, nem mesmo a caracterização ilusória ou provocante de suas devoções. Pouco importa seu objeto, esse objeto múltiplo e multiplicado, ao mesmo tempo encenado, denegrido e renegado. Em 
compensação, parece significativo e capital para isto que está em jogo aqui, que essa devoção, piedosa ou viciosa, termina por levar a uma queda que não apenas movimenta seu sentido, mas se detém em seus procedimentos, por uma forma de reflexão sobre eles. Essa queda, constituída em boa parte pela intervenção de um advérbio, vem duplicar a invocação de uma meditação sobre isso que ela implica. Brutalmente, mudando de ordem, o poema que pôde, como as litanias, indefinidamente se prolongar, detém-se sobre uma bifurcação relativa a seu próprio método. A voz que pronuncia a advertência sobre a qual ele se fecha, o faz em um sobressalto, exclamando, porque as palavras mais simples que ela vai lançar mudam abruptamente todas as perspectivas até então postas em jogo. Após tantas declinações da invocação por vezes livres até o ponto do jogo de palavras, o advérbio que surge para ser recusado, esse advérbio instabilizado pelo texto é então e a palavra é sublinhada pelo poema:

A todo preço e com qualquer tempo, mesmo nas viagens metafísicas. - Não mais agora.

(Rimbaud 1998: 253)

Certamente, esse advérbio é por si só suscetível de reinscrever a temporalidade, a cronologia que ela implica e as chances de narração que elas restituem ao sujeito. O poema é portanto fundado sobre o choque de dois registros de discurso, de um lado, aquele do sujeito de devoção, sujeito devoto, devotado - votado - e votado, desse fato, a se calar fora de seu apelo a isso que ele invoca, e, de outro, uma marca, um índice intolerável da integração na organização da temporalidade e do mundo. O texto é portanto atravessado pelo vetor de uma oração da qual se exclui aquele que a formula e se exclui em nome mesmo de seu êxtase, ou seja sua busca mística ou poética, - busca que deveria ser irônica ou controvertida:

À irmã Louise Vanaen de Voringhem: - Sua "corneta" azul voltada para o mar do Norte. - Para os náufragos.

À irmã Léonie Aubois d'Ashby. Chapéu! - a grama do verão zumbindo e poluindo. - Para a febre das mães e das crianças. (Rimbaud 1998: 297) ${ }^{19}$

No entanto, ele se fecha sobre um advérbio em que se lê o retorno abominado de um universo mental fundado sobre a organização, sobre o ordenamento, sobre a precaução e, portanto, sobre a cronologia e sobre a ação. Com insolência, o texto diz sua predileção. 
Privilegia o êxtase. Aí compreendidos mesmo aquele das viagens ditas metafísicas. Seu "A todo preço", que é a retomada degradada das fórmulas que precederam, introduz o retorno, de modo que não se possa duvidar do desespero que ela implica. Rimbaud escolhe, duramente e talvez sem acreditar. Mas escolhe a mesma coisa em última análise, a viagem metafísica à engrenagem temporal de onde surge a narração, que, quer se queira quer não, obrigará novamente o sujeito lírico a uma participação ativa. Não é ainda um voto piedoso, certamente. Talvez uma hipótese na contramão, que seu próprio tom é suficiente para denunciar. Porque este agora (alors), que não pode duravelmente se deixar afastar, retornará como força nas lluminações e sem dúvida na vida do poeta.

Quanto ao poema de Yves Bonnefoy, datado de 1959, intitulado também “Devoção" de modo a evocar expressamente Rimbaud, ele o retoma, explicitando o movimento rimbaudiano, para colocar a questão da escritura do poema. Como esse poema não é nesse aspecto um decalque de Rimbaud, apesar da referência explícita, ele também não segue seu caminho. A letra do texto comporta portanto ao mesmo tempo o traço rítmico característico do poema de Iluminações e seu andamento próprio. A invocação é aí, por exemplo, ao menos uma vez interrompida pelo parêntese do retorno do sujeito lírico que se permite repentinamente não apenas uma intrusão, mas uma confidência: ${ }^{20}$

Nos pintores da escola de Rímini. Eu quis ser historiador por angústia de vossa glória. Quisera apagar a história por zelo de vosso absoluto. ${ }^{21}$ (Bonnefoy 1998: 170)

Quanto à estrofe IV, ela vem introduzir, por outro lado, em relação à multiplicidade de objetos de invocação anteriores, uma outra preocupação, talvez espiritual e certamente de esperança. Eu a cito inteira, aqui, na impossibilidade de me decidir por desmantelá-la:

E sempre em cais de noite, em pubs, em uma voz a dizer Eu sou a lâmpada. Eu sou o óleo.

Nessa voz consumida por febre essencial. No tronco cinza do bordo. Numa dança. Nessas duas salas quaisquer, para a manutenção dos deuses entre nós. ${ }^{22}$ (ibidem)

Mas ocorre também que o poeta tome a metáfora do êxtase, ou da viagem metafísica, ao pé da letra, de onde derivam tantas docas, trens, ruas e passos difíceis, constituídos em 
itinerário, de onde deriva a evocação de tantos lugares marcantes para as artes e para a fundação de si, lugares mitológicos bem como reais dos quais a declinação estabelece o ponto de fuga dessa busca e - quem sabe? - dessa peregrinação, (“Nas capelas das ilhas. / Na Galla Placídia. Numa porta murada de tijolos cor de sangue sobre a tua fachada cinza, catedral de Valladolid. [...] Na minha morada em Urbino, entre o número e a noite. Em Santo Ivo da Sabedoria. Em Delfos onde se pode morrer") (idem: 169). ${ }^{23}$ A viagem, por interior que seja, encontra assim seus destinos. Encontra também a geografia que a exprime. A invocação rimbaudiana encontra, ainda, no sentido próprio, um desenho e um espaço.

Há mais, no entanto. Não somente a meditação sobre o deslocamento obrigatório do lirismo se confere assim os meios para se desdobrar e talvez mesmo de se analisar nessa figuração da viagem, mas ela exprime seu risco. O poema, com efeito, desde suas primeiras palavras, desde seu ponto de partida, coloca como regra a ascese que acompanha seu trajeto. Que não nos enganemos, as estações desse itinerário, ainda que correspondessem a lugares cardinais para o imaginário da criação, singularmente para o poeta, são áridas e permeadas ao mesmo tempo por urtigas e por pedras. Ao mesmo tempo, aí se reconhece, desde a primeira estrofe, o preço a pagar por essa excentricidade lírica, preço que não é nada menos que o da perda, da perda da presença em si do próprio sujeito lírico. O poema enuncia então explicitamente o que permanecia ainda latente em Rimbaud. No final desse percurso, mesmo se a perda se inscreva na abertura do poema, é o sujeito invocante que se encontra minado antes que sua palavra seja comprometida, ao menos, até a redenção esperada, mas sempre esperada para mais tarde.

\footnotetext{
Nas urtigas e nas pedras.

Nas "matemáticas severas". Nos trens mal iluminados de cada noite. Nas ruas de neve sob a estrela sem limite.

Eu caminhava, me perdia. E as palavras mal achavam seu caminho no terrível silêncio. Nas palavras pacientes e salvadoras. ${ }^{24}$ (ibidem)
}

Nenhuma esperança, com efeito, mesmo nas palavras pacientes e salvadoras, poderia remediar este desembaraço da participação do sujeito lírico, ainda que ele possa ser pressentido como poeticamente temível. Do eclipse do sujeito lírico ao da sua palavra, o passo 
foi dado, ao menos a título provisório, pois o poema de Yves Bonnefoy, que propõe sua devoção essencial ao lugar do poder poético, nomeia também sua ambiguidade.

Esse poema, que em muito ultrapassa essas poucas observações, rompe sem dúvida em outros pontos com o de Rimbaud. Referência cujos motivos ele radicalizou, emprestandoIhe especialmente uma outra perspectiva, ou textura concreta. Em suma, o êxtase desejado poderia não ser poeticamente desejável. O poema constitui o trajeto pelo qual o sujeito lírico poderia eventualmente aí aparecer, mas rapidamente ele muda de modo brusco de direção. Desde sua exclamação pronunciada, ele volta a descer de seus pontos climáticos a fim de que o sujeito lírico possa reintegrar sua história, que ele possa tornar-se novamente sujeito e, ao fim das contas, que ele volte a agir, em todo caso, até a admissão de uma esperança de manutenção dos deuses entre nós.

Não há muita dúvida de que os poemas ditos líricos se componham da sucessão desses retornos, como a proposição da expectativa de suspensão, seguida de sua resolução abreviada. Nessa perspectiva, nem precisaríamos dizer que não seria necessário muito para que eu afirmasse que as litanias, das quais partiram essas reflexões, são apoéticas, independentemente ao menos do que elas devem à encantação. Em compensação, a estrofe de Eliot que me interessou era precisamente poética por restabelecer essa pulsação segundo a qual, em um ritmo cardíaco, o sujeito lírico tinha se arremessado em direção ao lugar de seu êxtase para tão logo recomeçar a suspirar pela ausência de unidade.

Esse propósito não me pareceria, no entanto, completamente justo se ele não integrasse, ao menos a título de abertura, algumas observações sobre as derivações obrigatórias que resultam dessa impotência do poema lírico em permanecer em seu ponto climático. Com efeito, o objeto poético é muito complexo para não jogar com aquilo que deveria paralisá-lo e a poesia oferece ao menos dois recursos em suspensão aos quais conduzem os procedimentos exclamativos. O primeiro se relaciona a um retorno da narração e o segundo à música propriamente e à negociação de suas pausas.

Com efeito, mesmo na poesia dita lírica, o silêncio da narração jamais é sustentável por muito tempo. Pode-se fazer, como acontece ao natural, que ela não retorne sempre rapidamente. Não é o local para desenvolver esse ponto, que estava já latente no que foi dito sobre o verbo e que se encontra, por outro lado, precisamente ilustrado por um artigo de Yves 
Vadé sobre a poesia, cujo título mesmo “Du cristal à l'image mythe" (Vadé 1974) não deixa de ser evocador. A análise se detém, com efeito, em recolher na imagem em si, na aparência cristalizada e por isso estática que ela se atribui, a complicação mítica que será suscetível de retomar o relato (récit). Há, com efeito, razões de fundo para tais procedimentos. Visto que a elisão do sujeito lírico não se pode prolongar, sob pena de tédio, ou de saída do campo estético, o poema se colocará, em compensação, no dever de iluminar isso que designarei como os do desejo do sujeito lírico. Melhor dizer que ele relatará sua pulsação íntima.

Ocorre, de certo, que se a narração consiste bem, como creio, nesse exercício de mensuração da distância que separa sempre o sujeito que deseja do objeto de seu desejo, a ponto de que ele virá a se apagar ou a se tornar desajeitado (maladroite), segundo a palavra que sugeria René Girard, logo que houver convergência entre os dois, a narração precisa da dificuldade. Lembremo-nos de um dos motivos ordinários do conto que adensa os efeitos do que se propõe aqui: quando o príncipe deseja uma princesa, essa se encontra, em geral, longe dele, do outro lado do rio ou em algum castelo fora do alcance. Um exemplo assim simples testemunha a natureza profunda da narração, que não é outro senão estabelecer a relação entre os esforços bem sucedidos ou mal sucedidos do príncipe em se reaproximar de sua princesa e, portanto, se o exprimirmos em termos muito concretos, de mensurar pura e simplesmente a separação entre os dois parceiros. Lembremo-nos ainda do final desses mesmos contos, quando ele é feliz: eles enunciam todos a mesma descoberta de felicidade para se calarem depois de a terem enunciado. Da qualidade específica dessa felicidade, além do casamento e dos filhos a vir, nada mais é dito. Nada se poderia dizer. Segundo outras formas literárias, a distância ou a proximidade do sujeito e de seu objeto pode se medir de forma menos material sem que o princípio seja modificado e seus desdobramentos, se eles são tramados, em vez de serem lacônicos, não deixam nunca de se atualizar em muitas outras figurações do retomada da busca ou mais simplesmente da caça à felicidade. No poema, enfim, os termos da narração podem se interiorizar, como poeira existencial, a ponto de não haver mais nenhum gancho com o mundo exterior. De que importa a espessura da trama: o poema, todo poema, continuará oscilando entre presença desejante e gozo sincopado, até não mais discernir o que vai e vem entre um e outro. Um poeta também hábil em nomear, 
abstratamente por vezes, as intermitências do desejo e do ser como Du Bellay não deixa de escrever, assim, por exemplo, no soneto XXVIII, de L'Olive:

Je quier' cela, que trouver je recuse. (Du Bellay 1993: 30) ${ }^{25}$

Mas é assim que se distribui às vezes na poesia muito contemporânea, para além de toda anedota e de toda singularidade do sujeito lírico, essa batida reduzida a si mesma ou a ínfimas marcas, na qual desejo ler uma maneira de narração não figurativa. Em certos poemas de Celan, se não já no ritmo de certas estrofes de Eliot, esse balanço de uma narrativa tornada toda abstrata é por vezes mais figurado pela aproximação de formulações alternativamente positivas e negativas. Então, como se a circunstância não tivesse mais duração, o relato (récit) não demora mais que um sopro: o sopro da narração que então se confunde com o mesmo da vida.

Há, portanto, uma segunda categoria de lirismo que se relaciona com a música, vindo preencher o silêncio das palavras silenciosas. Talvez seja esse o ponto em que a poesia e as litanias terminem por se reencontrar. É talvez também o ponto em que as litanias readquirem, por seu ritmo, todo o melhor do restante que a tradição as fez cantar ou salmodiar, o que elas tinham perdido na sintaxe. Então a música, ou a musicalidade, resgata as síncopes do logos. Essa é a via da encantação.

Nietzsche associava Arquíloco, o pai da canção popular, a Homero, o poeta épico cuidadoso da narração, os dois ancestrais, dizia ele, da poesia grega (Nietzsche 2005: 46-51). Esse mito nietzscheano, se ele não é grego, associa ao mesmo tempo que opõe os dois recursos de uma palavra lírica que tenderia, uma vez alcançado o mais alto dela mesma, a um suspense.

Seria desnecessário dizer no entanto que todo poema verdadeiro abrange no mesmo ritmo sua vocação ao silêncio e seus diversos recursos contra esse mesmo silêncio e isso que se denomina poesia diz essencialmente esse batimento em que talvez o que se figura para se entregar à emoção do leitor seja a imagem da palpitação existencial que define, de modo que não ousamos, por essa vez, dizer universal, o sujeito lírico e todo o mundo. Acontece, ao final desse exame de algumas das estruturas desses poemas, de litanias ou mesmo das relações entre essa ou aquela figura da narração, que o sujeito lírico é de início aquele que, entre 
arrebatamentos e recaídas, atinge, ao mesmo tempo, seu possível e seu impossível, ousa esperar isso e é precisamente na medida em que se arrisca como o leitor, não menos desprovido que ele do desejo e do risco de esperar, que necessita, de onde quer que ela venha, de sua audácia e da incitação que ela lhe fornece.

\section{Post Scriptum ${ }^{26}$}

Gostaria de acrescentar uma curiosidade ao que precedeu. Uma curiosidade que tomei de empréstimo a Diderot, visto que ela atualiza a importância que ele atribui à narrativa (récit). Evocarei em seguida formas de poemas em que, apesar de uma renúncia total às circunstâncias, subsiste um resíduo de narração.

\section{1 - Diderot}

Lembremos de sua notável fábula sobre nosso gosto natural por narrar. Em Jacques, o Fatalista (Diderot 2006), ele se pergunta o que o povo vai procurar, logo cedo, na Place de Grève. ${ }^{27}$ Não, não é, diz ele, por desumanidade. Por outro lado, a verdadeira razão dessa atração se deve ao fato de que ele vai procurar na praça uma cena que ele possa contar quando voltar ao subúrbio. Em suma, segundo o narrador, que pretende recuperar as palavras de Jacques, uma execução, dita capital, não seria mais do que a narrativa que ela funda. No final das contas, sozinha, a narrativa (récit) é capital e o texto almeja nesse sentido:

Promovei no bulevar uma festa divertida, e vereis que a praça das execuções ficará vazia. O povo é ávido de espetáculos e corre para eles, porque se diverte quando os desfruta, e porque ainda se diverte pelo relato que faz deles ao voltar para casa. (Diderot 2006: 262)

Festa ou execução, pouco importa o pretexto, é o texto que conta. É o conto, são os contos que importam e a embriaguez da palavra torna-se no romance semelhante àquela que procura esta espécie de Pítia $^{28}$ portátil que constitui divina cabaça da qual Jacques nunca se separa. Por detrás dessas brincadeiras, o que se delineia é uma espécie de antropologia brincalhona fundada no desejo de narração, a ponto de mesmo a morte acabar, se não sempre por canções, ao menos pelas palavras. Mas não seria a mesma ideia que, com mais gravidade, encontra-se sob a pluma de um paleontólogo como Stephen Jay Gould que pode escrever a 
propósito de um homem Neandertal que nós somos criaturas que contam histórias, e que nós deveríamos nos chamar Homo narrator [...] mais do que Homo sapiens, que frequentemente não convêm (Gould 1994: 196).

Desejo de narrar? Mas e se o desejo de narração se devesse ao fato de que toda narração é narração do desejo? Isso poderia implicar na razão de sua ubiquidade, mascarada ou não, mas essa ubiquidade só pode ser multiforme.

A narração, em seu início, é relativa ao desejo. Talvez ela seja por si só uma maneira de decalque. O nó que liga uma a outro é constituído pela relação de realização do seu fracasso. A narração sempre se dá como uma consignação, como um registro do que virá. Vista assim, a narrativa é aquela dos acasos, ${ }^{29}$ felizes e infelizes inclusive, do desejo em relação ao seu objeto. Traduz sempre mais ou menos uma aproximação ou um distanciamento, uma separação ou uma união do sujeito desejoso desse último. Dito de outra forma, a narração tem essencialmente como função mensurar uma distância, às vezes temporal e espacial, obviamente flutuante, entre esses polos. A peripécia a aumenta ou diminui segundo a sorte que ela reserva ao obstáculo. A narrativa, que termina tão frequentemente por se constituir em busca, termina também por tomar os andamentos de alguns processos de medição, até mesmo de medida desse distanciamento, às vezes no espaço e no tempo (como em $A$ Bela Adormecida).

Isso retoma o que foi previamente dito sobre a poesia lírica, responsável como ela é por exprimir o desejo do sujeito. Ela, no entanto, se apressa em buscar ou em fazer buscar o desenlace, até mesmo em antecipá-lo, como se ele fosse o seu verdadeiro objeto, de modo que se encontra atravessada por duas energias contraditórias. A narrativa que a percorreu se apressa em direção a seu fim. Ela narra, se é feliz, uma viagem em direção a isto que, uma vez obtido, obliterará toda a necessidade de busca e de narrativas que poderiam ser feitas. Levará em direção a esse esquecimento pleno, fora de circunstância, em que um poeta como São João da Cruz se detém em "Noite Escura", no momento em que rompe com a narração que havia fornecido o ponto central de seu poema: entre os lírios esquecido. Mas the teria sido necessário atravessar a noite, a saída de si e de sua casa, para chegar a esse ponto, que o esquecimento impede de descrever adiante. Lá, onde não se trata mais de permanecer no êxtase, o poema, fora do registro ornamental das flores de lis, não tem mais nada a dizer. 
É um silêncio parecido que o conduz quando é dito o colapso provocado pelo infortúnio e esse último supera todas as possibilidades da linguagem. Há, portanto, uma tensão fundadora, especialmente sensível na poesia lírica, entre as duas vocações da literatura, uma sendo de narrar como o desejo segue e a outra de se calar se o sujeito se apodera de seu objeto ou se está muito abatido por sua tristeza. Que não seja objeto de surpresa que ela transforme tão frequentemente o poema em uma liça. ${ }^{30}$

\section{2 - São João da Cruz e Paul Celan}

Seguiremos recorrendo a novos exemplos. São dois poetas também tão distantes um do outro quanto se poderia pensar. No entanto, a aventura interior que eles designam não é completamente sem pontos em comuns. Eles de fato estão encarregados de nomear uma experiência de dissociação daquilo que não lhes importa nem um pouco. Dito de outra maneira, os dois aceitam abandonar. É isso que torna a singularidade deles tão preciosa para esse propósito: eles não têm, nem um nem outro, relações com o curso do mundo tal como ele segue, incluídos aí eles próprios. Poderíamos ser tentados a induzir dessa atitude uma renúncia à narração (narration). Ou não apenas ele não é nada, mas ele não é nada pelo simples fato de que eles são poetas e demasiadamente poetas, um e outro, para não retornar a ela, ainda que sob pena de alguns desvios. Disso resulta que aqueles que consumiram suas próprias histórias, podem ter ainda a incumbência de narrar no momento de cantar.

Quanto a São João da Cruz, os procedimentos permanecem relativamente simples. Paradoxalmente, ele tem tendência em substituir a narrativa da busca pelo êxtase por esse, que, no entanto, ele tinha preocupação de partilhar. Ao final dessa substituição, ele chegaria a esse novo paradoxo, segundo o qual é confiado à narração o fardo de exprimir aquilo que a ultrapassa, até mesmo o que a negaria, se ela o atingisse. Em suma, a destinação se encontra então figurada pelo caminho tomado. Dito de outra forma, o fim não se diria senão pela expressão de seus meios.

O que já foi evocado a propósito da estrutura de "Noite Escura", em que a narração do trajeto, que precedeu o encontro, toma em parte o lugar do comentário sobre o êxtase. Dessa narração (récit), conhecemos ao menos uma peripécia, visto que a terceira estrofe introduz na obscuridade desta noite a luz que brilha no coração do locutor: 
sem outra luz e guia

senão a que em meu coração ardia (Cruz 1991: 51)

Essa narrativa (récit) é a celebração de uma aventura feliz. Ele conduz ao encontro da amada que ele refere e evoca em duas estrofes em que se dizem metaforicamente a proximidade e a intimidade feliz de dois corpos. Entretanto, o acme dessa aproximação deixa a amada imóvel, esquecida e, passando o que pode ser dito, encerra-se sob o silêncio do auge já evocado (entre os lírios esquecido) (ibidem).

Esse poema é emblemático de um procedimento que São João da Cruz retoma no Cântico Espiritual, e que já estava em curso em uma parte do Cântico dos Cânticos bíblico.

Mas ainda há mais. Para preservar o dinamismo da chegada, a busca pode ainda continuar até o momento do reencontro. Nenhum desenlace na intimidade que se estabelece então, ou esse se acompanha de um renascimento. O turbilhão ou a palpitação de amor que se propõem, inventam assim suas próprias figuras de mobilidade perpétua. Dessa forma, a morte, na "Chama de amor vivo", está voltada para sempre para a vida, que se alimentará ela mesma de novas maneiras de morrer ("matando, morte em vida é trocada"). ${ }^{31}$ Além disso, o apogeu do amor o chama de maneira tão evidente a um acréscimo de amor que o último verso do poema lá estabelece um momento climático, um perpétuo recomeço ("quão delicadamente me enamoras") (idem: 55).

Tudo acontece como se o poema se fizesse dotar de uma via de narração virtual além de sua chegada ao porto. Estou perfeitamente ciente entretanto que os poetas talvez tenham outros recursos para conjurar o imobilismo das alegrias que eles expõem. Algumas outras figuras poéticas chegam a sobrepor um futuro à plenitude e, contra toda expectativa, estabelecem uma dialética daquilo que está repleto. Trata-se então de outros acionadores de um infinito perpetuamente vindouro, outras dinâmicas a procurar, por exemplo, em certas metáforas, mais vivas que outras, assim a chama para São João da Cruz ou os oxímoros susceptíveis de impor, neste mesmo poema, como às vezes em T. S. Eliot, desse modo ainda, certos procedimentos sobre os quais repousam o movimento e a emoção do Paraíso de Dante, e até o brilho contraditório da fórmula do Apocalipse segundo o qual Ele é, Ele era, Ele vem. Trata-se sempre de estabelecer, no lugar da morada, uma revelação que é, ao mesmo, uma promessa sempre renovada, um dom para sempre crescente. Ainda seria necessário verificar 
que o dinamismo latente da metáfora da chama para São João da Cruz ou o jogo com o tempo do verbo ser/estar no Apocalipse também não fazem apelo a uma narração (narration) subreptícia. Da mesma maneira, aliás, São João da Cruz recorre também às oscilações e às inversões entre proposições positivas e proposições negativas que encontraremos em Paul Celan, para instalar, ainda essa vez, outra vibração desse efeito de superposição, uma perpétua dinâmica para seus textos.

Pode-se reconhecer aí oscilações entre os polos da falta e da plenitude, nos quais se reencontra a matriz verdadeira da narrativa (récit). Trata-se sempre de perpetuar o desejo em si satisfazendo-o e, no final das contas, de reatar com a eventualidade de ter ainda e sempre algo para narrar.

A mensagem de São João da Cruz era de um místico. Ele conseguiu exprimir o que transmite a expressão. Paul Celan deve às vezes calar e designar o que a Segunda Guerra Mundial e a Shoah tiveram de inominável. Nem por isso sua obra deve disputar com o mutismo do desespero. Ela procede, também por isso, da superação dos limites do que pode se formular diretamente.

É essa superação, quer dizer, são suas formas que me detêm aqui. O poeta não tem e não tinha mais nada a narrar. Mas o poema diz por ele a partir de suas recusas em dizer. Paul Celan recusa toda anedota, não se detêm em nenhuma singularidade, não descreve as pessoas evocadas, às vezes as reduz a pronomes pessoais sem referentes, até que se deixe compreender apenas a pulsação de uma narração (narration) desatada de circunstâncias, quase pontos de apoio, abstrata, se quisermos, e em que às vezes não se diz mais, como em São João da Cruz, que a aproximação insólita de formulações alternativamente positivas e negativas. É então um sopro que corre, e eu gostaria de poder falar, a esse respeito, sobre narração não figurativa.

Assim, em "Cologne, am Hof":

\author{
Havia quem falasse, quem se calasse, \\ quem seguisse o seu caminho. \\ Banidos e perdidos \\ Estavam em casa. (Celan 1993: 67)
}


Mais protagonistas então que não são desnudados, até não ser mais do que cada um e não importa quem. Mais objetos, senão aqueles que não pararam de oscilar do sim ao não, do vazio ao repleto. Da pessoa do sujeito lírico restam apenas fragmentos, uma designação neutra e minimizadora, ou ainda a aproximação de proposições alternativamente positivas e negativas ("Havia quem falasse, quem se calasse"). Permanece contudo a relação ainda de uma palpitação que traz o traço da instabilidade existencial. É nesse abandono do que é circunstancial, nessa renúncia da narrativa encadeada (récit), nessa recusa de personalizar $o$ ou os sujeitos líricos que entrevejo uma maneira de narração não figurativa. Ao inverso do que foi dito anteriormente sobre a relação do lirismo e da exclamação, são no conjunto os verbos que governam as estrofes, às vezes se contradizendo ("Havia quem falasse, quem se calasse"). Os atos se sucedem. Os adjetivos são pouco numerosos. Mas a enumeração dos momentos verbais termina por constituir uma espécie narrativa (récit) nua, homogênea e, sobretudo, com efeitos silenciados, o que não impede a potência emotiva da obra.

A sobriedade da narrativa (récit) no entanto suprime os signos do que havia considerado anteriormente como constitutivo do lirismo. Ações são enumeradas como estando fora do desejo de qualquer sujeito e não são nesse caso o objeto de nenhum contentamento e de nenhuma decepção. Mas é exatamente esse mutismo que está gritando - prova de que não se podem reduzir os paradoxos da poesia. Nessa abstração em que as imagens rigorosamente falando são raras, tudo se torna imagem. Talvez ainda a errância de Banidos e Perdidos, em "Cologne, am hof" seja menos patente do que a recusa do pathos. A abstinência nesse caso é total daquilo que um Michel Deguy poderia considerar como próprio do lirismo, mas de outros caminhos, outras possibilidades e, certamente, do milagre do poema, a emoção surge. É que, lá onde a singularidade e a circunstância não têm mais curso, permanece da narrativa apenas uma pulsação reduzida ao ínfimo e esse último se confunde com o que é próprio da vida e da estranheza do viver.

Dessa forma a narração (narration) diz, por predileção, o desejo não realizado e morre com aquele que se realiza. A literatura se desvanece para ser privada de narrativa. Ela está em sofrimento no momento em que seus personagens estão completos, muito felizes ou muito sensatos. Quanto à poesia lírica, que permitiu apreender esses trajetos, ela não parece ser 
capaz de suportar muito tempo o êxtase de seu sujeito. Deixo para pensar o que se pode deduzir de nossas artes instáveis como nós e para as quais a iluminação não dura.

\section{NOTAS}

${ }^{1}$ Tradução do texto “Le lyrisme impossible: poèsie et litanies” (Astier 1996: 231-251).

${ }^{2}$ Título original: Dans le leurre du seuil.

3 Tradução semântica: "Esse amor que a todos abandonou".

${ }^{4}$ Tradução semântica: “A vantagem sobre a mentira valente / É o consolo sincero”.

5 Tradução semântica: "Newton despedaçou a encenação".

${ }^{6}$ Tradução semântica: “[...] sob os traços tão correntes quanto ambíguos do poema”.

${ }^{7}$ Nota da tradução: No original - "maladroit".

${ }^{8}$ Nota da tradução: “Mirroir aux alouettes”, no original, é uma expressão que data do período anterior à Primeira Guerra. Era uma armadilha feita por caçadores para capturar andorinhas. Preparada com pequenos pedaços de vidro presos na ponta de bastões, os caçadores criavam efeitos luminosos ao agitá-los na luz.

${ }^{9}$ Nota da tradução: Em francês, "Mercredi des Cendres", versão para “Ash-Wednesday”, de T. S. Eliot.

${ }^{10}$ Maulpoix (1989) e Octavio (1965), citados por Jean-Michel Maulpoix.

${ }^{11}$ No original: "O toison, moutonnant jusque sur l'encolure! / O boucles! O parfum chargé de nonchaloir! Êxtase!"

${ }^{12}$ No original: "Lady of silences / Calm and distressed / Torn and most whole / Rose of memory / Rose of forgetfulness / Exhausted and life-giving /Worried reposeful / The single Rose." (Eliot 1969)

${ }^{13}$ Assim ocorre nas quatro últimas estrofes do mesmo poema, nas quais as fórmulas rituais, além da queixa que enunciam, designam a linha de fuga do poema e o que ela constitui, adicionando-lhe aquilo que lhe é radicalmente contrário.

${ }^{14}$ No original: "Terminé le tourment / D’amour insatisfait / Et celui plus cruel /De l'amour satisfait".

${ }^{15}$ No original: "Rendons grâce à la Mère / Pour le jardin / Où tout amour prendre fin". 
16 No original: "tranquille et desolée, dechirée et entière, épuisée et vivificante, tourmentée et reposante, mémoire et oubli".

${ }^{17}$ Mas, ao inverso, para dar apenas um único exemplo, de modo similar à prática de Eliot, Rimbaud, em um poema como "Manhã de embriaguez" ("Matinée d'ivresse"), amarra a carga de esperança que se encontra, por natureza, contida na ideia e na própria palavra da promessa, a seu contrário: essa promessa, essa violência!

18 Podem ser encontrados: o de Rimbaud na edição citada das Iluminações e o de Bonnefoy, em Do Movimento e da Imobilidade de Douve, no original Du mouvement e de l'Immobilité de Douve, seguido de Reinante ontem Deserto (Hier régnant désert).

${ }^{19}$ No original: “A ma soeur Louise Vanaen de Voringhem: - Sa cornette bleue tournée à la mer du Nord - Pour le naufragés. / A ma soeur Léonie Aubois d’Ashby. Baou - I'herbe d'été bour - / donnante et puante. - Pour la fièvre des mères et des enfants".

20 Nota da tradução: Para o poema "Devoção", de Bonnefoy, foi utilizada a tradução literária consagrada, preparada por Mário Laranjeira. Parece relevante observar, contudo, que a versão de Laranjeira, quando pensada nos termos propostos pelo ensaio, parece perder alguns dos elementos que aproximam os dois poemas de mesmo título. Nesse sentido, no rodapé, acrescentamos uma tradução semântica dos trechos transcritos, com ligeiras divergências em relação ao trabalho de Laranjeira.

${ }^{21}$ No original: “Aux peintre de l'école de Rimini. J'ai voulu être historian par angoisse de votre gloire. Je voudrais effacer l'histoire par souci de votre absolu." Tradução semântica: "Aos pintores da escola de Rimini. Eu gostaria de ser historiador pela angústia de sua glória. Eu gostaria de apagar a história por cuidado com seu absoluto".

${ }^{22}$ No original: “Et toujours à des quais de nuit, à des pubs, à une voix disant: Je suis la lampe, Je suis l'huile. / A cette voix consumée par une fièvre essentielle. Au tronc gris de l'érable. A une danse. A ces deux salles quelconques pour le maintien des dieux parmi nous". Tradução de Mário Laranjeira, edição referida. Tradução semântica: "E sempre às docas ao anoitecer, aos pubs, a uma voz dizendo: Eu sou a luz. Eu sou o óleo. / A essa voz consumida por uma febre essencial. Ao tronco cinza de bordo. A um baile. A essas duas salas quaisquer pela manutenção dos deuses entre nós".

${ }^{23}$ No original: "Aux chapelles des îles. A Galla Placidia. A une porte murée de briques couleur du sang sur ta façade grise, cathédrale de Valladolid. [...] A ma demeure à Urbin entre le nombre et la nuit A Saint-Yves de la sagesse. A Delphes ou l’on peut mourir". Tradução semântica: “Às capelas das ilhas. A Galla Placidia. A uma porta murada de tijolos cor de sangue sobre tua fachada cinzenta, Catedral de Valladolid. [...] A minha casa em Urbin, entre o número e a noite. A Saint-Yves da sabedoria. A Delfos, onde se pode morrer".

${ }^{24}$ No original: “Aux orties et aux pierres. /Aux 'mathemátiques sévères'. Aux trains mal éclairés de chaque soir. Aux rues de neige sous l'étoile sans limite. / J'allais, je me perdais. Et le mots trouvaient mal leur voie dans le terrible silence. - Aux mots patients et sauveurs." Tradução semântica: "Às urtigas e às pedras. Aos 'matemáticos 
severos'. Aos trens mal iluminados de cada noite. Às ruas de neve sob a estrela sem limite. Eu estava indo, eu me perdi. E as palavras estavam erradas em seu caminho no terrível silêncio. Às palavras pacientes e salvadoras". ${ }^{25}$ Tradução semântica: “Eu desejo aquilo que me recuso a encontrar."

${ }^{26}$ Este Post Scriptum foi enviado pela autora, exclusivamente para a presente publicação.

${ }^{27}$ Nota da tradução: Place de Grève (atualmente Place de l'Hotel de Ville) é uma praça que ficava às margens do Rio Sena, uma praia feita de cascalho e areia (grève) onde logo se estabeleceu um porto. A partir do século XII, instala-se aí um mercado, que atrai homens em busca de trabalho. Durante o Antigo Regime, era usada para execuções e, durante a Revolução Francesa, foi o lugar escolhido para a montagem da primeira guilhotina. Daí ter sido escolhida como exemplo: historicamente era um cenário onde se desenrolava toda a sorte de acontecimentos propícios à criação de narrativas.

${ }^{28}$ Nota da tradução: Pítia ou pitonisa era a sacerdotisa do templo de Apolo, em Delfos, conhecida por suas profecias, inspiradas por Apolo.

${ }^{29}$ Nota da tradução: no original: aleas. Poderia ser traduzido por acasos, riscos, causalidades, destinos, ventura, imprevistos; algo imprevisível, frequentemente com um tom desagradável.

${ }^{30}$ Nota da tradução: Liça é o campo delimitado que se localizava em lugares próximos de castelos medievais, onde ocorriam justas, torneios e combates.

${ }^{31}$ No original: "Matando, muerte en vida la has trocado".

${ }^{32}$ No original:

Einiges sprach in die stille, einiges schwieg,

ieniges ging seiner Wege.

Verbannt und Verloren

waren daheim. 


\section{Bibliografia}

Althen, Gabrielle (2012), La Splendeur et l'Echarde, Paris, Corlevour.

-- (1996), "Le lyrisme impossible: poèsie et litanies", in Le sujet lyrique en question, Bordeaux, Presses Universitaires de Bordeaux, pp. 231-251

Baudelaire, Charles (1961), "La Chevelure", in Oeuvres Complètes, Paris, Gallimard, 25. (Tradução brasileira de Ivan Junqueira. in Baudelaire, Charles (1985), As Flores do Mal, tradução, introdução e notas de Ivan Junqueira, Rio de Janeiro, Nova Fronteira, 159.

Bonnefoy, Yves (1970), Poésie, Paris, Gallimard. (Tradução brasileira: Bonnefoy, Yves (1998), Obra poética, tradução e organização de Mário Laranjeira, São Paulo, lluminuras.)

Celan, Paul (1991), Grille de parole (Sprachgitter), trad. par Martine Broda, éd. Christian Bougois, 57. (Tradução para o português, de João Barrento e Y. K. Centeno, in CELAN, Paul (1993), Sete Rosas mais Tarde, Lisboa, Cotovia.)

Char, René (1983), Oeuvres Complètes, Gallimard, La Pléiade, 305.

Collot, Michel (1994), “Pierre Reverdy”, Europe (1994), no 777-778, pp. 35-42.

Cruz, São João da (1991), Poesias Completas, tradução de Maria Salete Bento Cicaroni, prefácio de Felipe B. Pedrosa Jiménez, São Paulo, Consejería de Educação de la Embajada de España.

Deguy, Michel (1961), Les Poèmes de la presqu'ile, Paris, Gallimard, 139.

Diderot, Denis (2006), Obras, IV. Jacques, o fatalista e seu amo, organização, tradução e notas de J. Guinsburg, São Paulo, Perspectiva.

Du Bellay (1993), Oeuvre poétique, tome I, édition D. Aris et S. Joukovsky, Paris, Classiques Garnier.

Eliot. T. S. (1963), Collected Poems. 1909-1962, London, Faber and Faber. [Tradução brasileira: "Quarta-feira de cinzas", in Eliot, T. S. (1981), Poesia, tradução, introdução e notas de Ivan Junqueira, Rio de Janeiro, Nova Fronteira, pp. 121-130 ] 
Girard, René (1951), Mensonge romantique et vérité romanesque, Paris, Grasset, 306. [Tradução brasileira: Girard, René (2009) Mentira Romântica e Verdade Romanesca, tradução de Lilia Ledon da Silva, São Paulo, É Realizações. N.T.]

Gould, Stephen Jay (1994), "So near and yet so far", The New York Review of Books, v. 41, no. 17, 26, citado e traduzido por Berque Augustin (1996), Etre humains sur la terre, Paris, Gallimard, 196.

Maulpoix, Jean-Michel (1989), La voix d'Orphée, Paris, Jose Corti, 72.

Nietzsche, Friedrich (1949), La naissance de la tragédie, tradução do alemão por Geneviève Bianquis, Gallimard, 50. [Tradução brasileira: Nietzsche, Friedrich (2005), O Nascimento da Tragédia. Ou helenismo e pessimismo, tradução de Heloísa da Graça Burati, São Paulo, Rideel.)

Paz, Octavio (1965), L’Arc et la lyre, Paris, Gallimard, 82. [Tradução brasileira: Paz, Octavio (2012), O Arco e a Lira, tradução de Ari Roitman e Paulina Wacht, São Paulo, Cosac Naify.

Rimbaud, Arthur (1973), Poésie, Une saison en enfer, Illuminations, Paris, Gallimard, 176. (Tradução brasileira de Ivo Barroso, in Rimbaud, Arthur (1998), "Vigílias", in Prosa Poética, tradução, prefácio e notas de Ivo Barroso, Rio de Janeiro, Topbooks).

Starobinski, Jean (1968), "René Char e a definição do poema", Courrier du centre international d'études poétiques, Bruxelas.

Vadé, Yves (1974), "Du cristal à l'image mythe", in Mythe e création, textes réunis par Pierre Cazier, Lille, P.U. de Lille. 
Colette Astier publicou também sob o pseudônimo literário de Gabrielle Althen. Foi professora emérita da Université de Paris $X$, Nanterre, e membro do grupo de pesquisas "Littérature et poétique comparées". Publicou, entre outros títulos: Le Mythe d'Oedipe; Europe, Reflets Littéraires, (com Claude de Grève) e Poèsie et Mystique (com Claude Léroy). Participou de um encontro organizado pelo grupo de pesquisa "Problématique et analyse des modernités littéraires" (Universidade Michel de Montaigne - Bordeaux III) do qual derivaram duas publicações dedicadas ao problema teórico do sujeito lírico: Figures du Sujet Lyrique (Presses Universitaires de France, 1996) e Le Sujet Lyrique en Question. (Presses Universitaires de Bordeaux, 1996). O texto traduzido consta do primeiro livro. Foi acrescido de um pós-escrito preparado pela autora para esta edição. As tradutoras são professoras da Universidade Federal de São Paulo (UNIFESP, Guarulhos). 